Revue des patrimoines

$37 \mid 2018$

Jardins collectifs : de l'abbé Lemire aux jardins d'insertion. Typologies - Expériences - Enjeux de conservation

\title{
LE NUMERO EN BREF - Jardins collectifs : de l'abbé Lemire aux jardins d'insertion. Typologies - Expériences - Enjeux de conservation
}

Community gardens from the Abbé Lemire in the late nineteenth century to today's 'back-to-work' gardens; types, experiences and conservation issues

Responsables scientifiques : Marie-Hélène Bénetière, Sophie Cueille et Françoise Dubost

\section{(2) OpenEdition Journals}

Édition électronique

URL : http://journals.openedition.org/insitu/19709

DOI : 10.4000/insitu. 19709

ISSN : 1630-7305

Éditeur

Ministère de la culture

Référence électronique

Responsables scientifiques: Marie-Hélène Bénetière, Sophie Cueille et Françoise Dubost, « LE NUMERO EN BREF - Jardins collectifs : de l'abbé Lemire aux jardins d'insertion. Typologies Expériences - Enjeux de conservation », In Situ [En ligne], 37 | 2018, mis en ligne le 14 décembre 2018, consulté le 19 avril 2019. URL : http://journals.openedition.org/insitu/19709 ; DOI : 10.4000/ insitu. 19709

Ce document a été généré automatiquement le 19 avril 2019.

\section{(c) (i) () $\Theta$}

In Situ Revues des patrimoines est mis à disposition selon les termes de la licence Creative Commons Attribution - Pas d'Utilisation Commerciale - Pas de Modification 4.0 International. 


\section{LE NUMERO EN BREF - Jardins collectifs : de l'abbé Lemire aux jardins d'insertion. Typologies - Expériences - Enjeux de conservation}

Community gardens from the Abbé Lemire in the late nineteenth century to today's 'back-to-work' gardens; types, experiences and conservation issues

Responsables scientifiques : Marie-Hélène Bénetière, Sophie Cueille et Françoise Dubost

1 Les seize articles réunis dans ce numéro s'inscrivent dans quatre grands axes de réflexion: historique, socio-économique, géographique et esthétique, l'introduction générale replace le sujet dans son contexte actuel et interroge sur la question de la patrimonialisation de ces jardins. La dimension historique est abordée dans quatre contributions de Port-Royal-des-Champs au XVII ${ }^{\mathrm{e}}$ siècle aux jardins partagés parisiens du $\mathrm{XXI}^{\mathrm{e}}$ siècle, cinq articles s'intéressent aux questions socio-économiques comme le développement durable des villes et des zones péri-urbaines, la santé et le lien social; l'approche géographique est présente dans trois articles depuis Marseille jusqu'en Finlande, et enfin, cinq textes relèvent de la dimension esthétique de ces jardins, qu'ils soient créés par des artistes ou qu'ils aient pour mission d'embellir la vie.

2 Une bibliographie donne un aperçu de la richesse du sujet tandis qu'une "brève » est consacrée au guide des sources des archives des parcs et jardins.

3 Ce numéro de la revue ne traite pas tous les aspects de ce vaste sujet mais offre une large vision de la diversité des questions qui relèvent tant du patrimoine que du bien-être de nos contemporains. 
4 Community gardens from the Abbé Lemire in the late nineteenth century to today's 'back-to-work' gardens; types, experiences and conservation issues

5 The sixteen articles presented in this number of the review can be divided into four main chapters, a historical one, a socio-economic one, a geographical one and an aesthetic one and addresses the issue of the patrimonialization of the gardens. Garden history is addressed in four contributions which cover topics ranging from the seventeenth-century Port-Royal-des-Champs to the shared community gardens of present-day Paris. Five articles are concerned with socio-economic questions such as sustainable development in cities and in peri-urban zones, health issues and social relationships. Three articles of geographical interest present studies ranging from Marseilles to Finland. Finally, five articles look at the aesthetic aspects of these gardens, with places designed by artists or simply intended to make life more beautiful.

6 A bibliography offers a suggestion of how rich this subject is and a short notice is also devoted to a guide on the archival sources concerning parks and gardens.

7 This collection of articles obviously cannot deal with all the facets of what emerges as a vast field, but it hopes to offer as broad a view as possible of the variety of questions that concern both the heritage and the well-being of our contemporaries. 